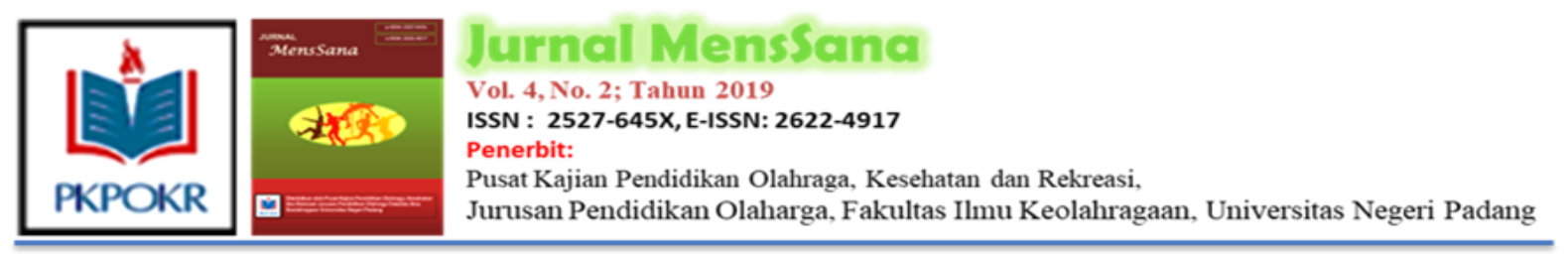

\title{
PENGEMBANGAN BUKU AJAR ILMU GIZI OLAHRAGA PADA MAHASISWA IKIP BUDI UTOMO MALANG: STUDI KETRAMPILAN BERPIKIR KRITIS
}

\author{
Paulus Rah Adi Pawitra ${ }^{1}$, Sigit Susilo ${ }^{2}$ dan Wiwik Kusmawati ${ }^{3}$ \\ 1,2,3 Program Studi Pendidikan Jasmani Kesehatan dan Rekreasi, Fakultas Pendidikan Ilmu Eksakta dan \\ Keolahragaan, IKIP Budi Utomo Malang. Jalan Simpang Arjuno 14 B Malang, 65119, Indonesia. \\ * Korespondensi Penulis. E-mail: super_paitro@yahoo.com
wiwikkusmawati@gmail.com
wiwagatess70@gmail.com²
}

\begin{abstract}
Abstrak
Penelitian ini bertujuan untuk mengetahui kemampuan berpikir kritis mahasiswa Pendidikan Jasmani Kesehatan dan Rekreasi IKIP Budi Utomo Malang pada pengembangan buku ajar Ilmu Gizi Olahraga. Penelitian ini merupakan penelitian pengembangan buku ajar Ilmu Gizi OLahraga. Pengembangan buku ajar Ilmu Gizi Olahraga ini mengacu pada model 4D yang dikembangkan olehThiagarajan, dkk. (1974) yang terdiri dari 4 tahap yaitu Define, Design, Development, dan Disseminate, dimodifikasi untuk disesuaikan dengan penelitian ini. Berdasarkan hasil penelitian dapat disimpulkan bahwa pengembangan buku ajar Ilmu Gizi Olahraga dapat meningkatkan kemampuan berpikir kritis mahasiswa Pendidikan Jasmani Kesehatan dan Rekreasi IKIP Budi Utomo Malang.
\end{abstract}

Kata Kunci: Ketrampilan Berpikir Kritis , Buku ajar, Ilmu Gizi Olahraga

\section{DEVELOPMENT OF SPORTS NUTRITION SCIENCE TEACHING IN UTOMO MALANG CULTURAL STUDENTS: CRITICAL THINKING SKILLS STUDY}

\begin{abstract}
This study aims to determine the critical thinking skills of Physical Education and Recreational Education IKIP Budi Utomo Malang students in the development of Sports Nutrition textbooks. This research is a research development of OLahraga Nutrition Science textbook. The development of the Sports Nutrition textbook refers to the $4 D$ model developed by Chiagarajan et al. (1974) which consists of 4 stages, namely Define, Design, Development, and Disseminate, modified to suit this research. Based on the results of the study it can be concluded that the development of Sports Nutrition textbooks can improve the critical thinking skills of students of Physical Education and Recreation IKIP Budi Utomo Malang.
\end{abstract}

Keywords: Critical Thinking Skills, Textbooks, Sports Nutrition

\section{PENDAHULUAN}

Direktorat Jenderal Pendidikan Tinggi (2009) mengatakan bahwa buku ajar merupakan buku pegangan untuk suatu mata kuliah yang ditulis dan disusun oleh pakar bidang terkait dan memenuhi kaidah buku teks. Dalam bidang pendidikan, buku ajar memiliki kaitan erat dengan proses pembelajaran dan kurikulum. Buku ajar adalah sarana bagi keterlaksanaan pendidikan dan pembelajaran. Selama pembelajaran, guru dapat mengelola kegiatan belajar dengan bantuan buku. Mahasiswa atau mahasiswa dapat mengikuti kegiatan pembelajaran melalui sarana buku. 

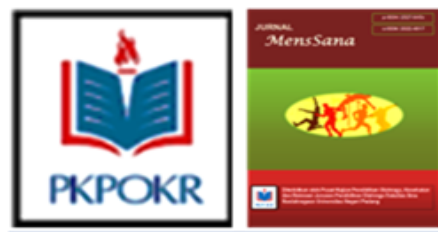

Ilmu Gizi Olahraga adalah salah satu mata kuliah wajib dalam Program Studi Pendidikan Jasmani Kesehatan dan Rekreasi IKIP Budi Utomo Malang. Ilmu Gizi Olahraga adalah ilmu yang mempelajari hubungan antara pengelolaan makanan dengan kinerja fisik yang bermanfaat untuk kesehatan, kebugaran, pertumbuhan anak dan pembinaan prestasi olahraga, khususnya olahragawan. Mata kuliah Ilmu Gizi Olahraga bertujuan untuk memahami hubungan antara nutrisi, gaya hidup dan kinerja fisik. Olahragawan harus mempunyai gizi yang sesuai untuk memperoleh kesehatan optimal dan kemampuan fisik sehingga memungkinkan mereka untuk bertahan dalam latihan fisik yang keras dan mampu mempertahankan penampilan yang baik selama pertandingan.

Wawancara dengan mahasiswa Program Studi Pendidikan Jasmani Kesehatan dan Rekreasi diperoleh hasil bahwa $80 \%$ mahasiswa kurang tertarik dengan mata kuliah Ilmu Gizi Olahraga. Mereka menganggap mata kuliah Ilmu Gizi Olahraga tidak ada kaitannya dengan dunia olahraga. Kenyataan ini membuat perkuliahan Ilmu Gizi Olahraga kurang kebermaknaannya. Sebagian besar mahasiswa PJKR menganggap Ilmu Gizi Olahraga adalah mata kuliah yang sulit. Tidak mengherankan jika hasil belajar Ilmu Gizi Olahraga mahasiswa Program Studi PJKR khususnya di IKIP Budi Utomo Malang masih tergolong rendah. Setiap ujian akhir semester Kriteria Ketuntasan Minimal (KKM) hanya $45 \%$ sampai $55 \%$.

\section{METODE}

Pengembangan buku ajar Ilmu Gizi Olahraga ini mengacu pada model 4D yang dikembangkan oleh Thiagarajan, dkk. (1974) yang terdiri dari 4 tahap yaitu Define, Design, Development, dan Disseminate, yang dimodifikasi untuk disesuaikan dengan penelitian ini.

\section{a. Tahap Define}

Pada tahap define ini, melakukan analisis kebutuhan instruksional yang diperlukan untuk pengembangan buku ajar yang meliputi langkah-langkah: (1) Menganalisis kompetensi dasar mata kuliah Ilmu Gizi Olahraga, (2) Mengidentifikasi permasalahan pembelajaran, serta (3)
Mengidentifikasi kelemahan dan kekurangan buku ajar Ilmu Gizi Olahraga.

b. Tahap Design

Tahap design ini dilakukan untuk menghasilkan draft awal buku ajar Ilmu Gizi Olahraga.

\section{c. Tahap Develop}

Tahap develop ini bertujuan untuk merevisi draft awal buku ajar yang telah disusun pada tahap design. Revisi berdasarkan oleh proses validasi yang dilakukan oleh ahli materi dan media. Setelah validasi dan revisi selesai dilakukan, maka dilakukan tes pengembangan yang meliputi uji perorangan, kelompok kecil dan Penelitian Tindakan Kelas (PTK).

\section{d. Tahap Disseminate}

Pada tahap desiminate ini adalah penyebarluasan buku ajar untuk digunakan diperkuliahan Ilmu Gizi Olahraga khususnya untuk Program Studi Pendidikan Jasmani Kesehatan dan Rekreasi IKIP Budi Utomo Malang.

\section{e. Indikator Keberhasilan Tindakan}

Indikator keberhasilan terhadap kemampuan berpikir kritis dilihat dari perbandingan hasil sebelum dan sesudah penelitian pengembangan. Tindakan dikatakan berhasil apabila terdapat peningkatan.

Cara perhitungan nilai persentase adalah sebagai berikut :

Nilai persentase $=$ Skor perolehan X 100\%

$$
\text { Skor Maksimal }
$$

Nilai persentase keterampilan berpikir kritis yang diperoleh dari perhitungan kemudian dikategorikan sesuai dengan tabel 1.

Tabel 1. Kategori Persentase KeterampilanBerpikir Kritis

\begin{tabular}{ll}
\hline \multicolumn{1}{c}{ Interpretasi (\%) } & \multicolumn{1}{c}{ Kategori } \\
\hline $81,25<\mathrm{X} \leq 100$ & Sangat tinggi \\
$71,50<\mathrm{X} \leq 81,25$ & Tinggi \\
$62,50<\mathrm{X} \leq 71,50$ & Sedang \\
$43,75<\mathrm{X} \leq 62,50$ & Rendah \\
$0<\mathrm{X} \leq 43,75$ & Sangat rendah \\
$81,25<\mathrm{X} \leq 100$ & Sangat tinggi \\
\hline
\end{tabular}



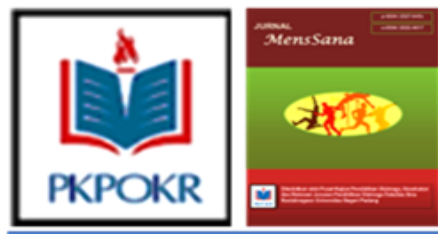

Jurnal MensSand

Vol. 4, No. 2; Tahun 2019

ISSN : 2527-645X, E-ISSN: 2622-4917

Penerbit:

Pusat Kajian Pendidikan Olahraga, Kesehatan dan Rekreasi.

Jurusan Pendidikan Olaharga, Fakultas Ilmu Keolahragaan, Universitas Negeri Padang

\section{HASIL DAN PEMBAHASAN (70\%)}

\section{Hasil Penelitian}

\begin{tabular}{lcc}
\hline \multicolumn{1}{c}{ Tindakan } & Sebelum & Sesudah \\
\hline Persentase & $45 \%$ & $81 \%$ \\
Kategori & Kurang & Tinggi \\
\hline
\end{tabular}

Berdasarkan hasil analisis tes, pengembangan buku ajar Ilmu Gizi Olahraga dapat meningkatkan kemampuan berpikir kritis mahasiswa Pendidikan Jasmani Kesehatan dan Rekreasi IKIP Budi Utomo Malang. Hasil keterampilan berpikir kritis mahasiswa PJKR IKIP Budi Utomo Malang pada pengembangan buku ajar Ilmu Gizi Olahraga adalah sebagai berikut :

Tabel 1. Persentase Keterampilan Berpikir Kritis Mahasiswa PJKR IKIP Budi Utomo Malang

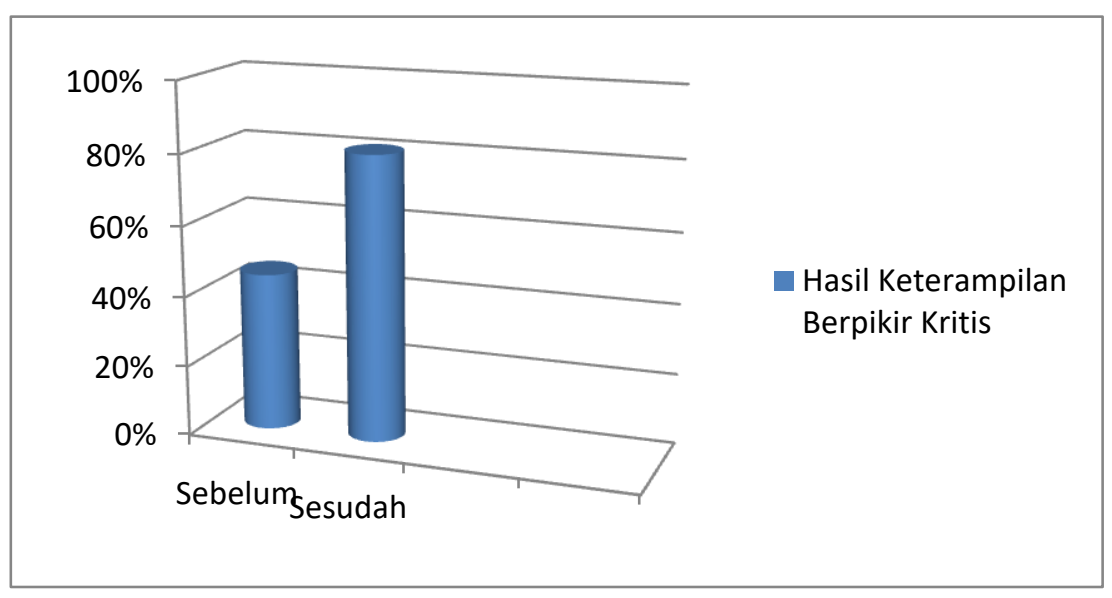

Gambar 1. Persentase Keterampilan Berpikir Kritis Mahasiswa PJKR IKIP Budi Utomo Malang pada

\section{Pembahasan}

\section{Pengembangan Buku Ajar Ilmu Gizi Olahraga}

Adanya mahasiswa yang merasa kesulitan dalam menerapkan pengetahuan maupun konsep yang diketahuinya untuk menyelesaikan masalah mengindikasikan bahwa mahasiswa harus banyak berlatih dalam menerapkan konsep atau pengetahuan yang mereka miliki agar keterampilan berpikir kritisnya dapat diberdayakan. Keterampilan berpikir kritis mahasiswa yang masih tergolong kurang mengindikasikan bahwa perlu diadakan evaluasi terhadap proses kegiatan pembelajaran yang digunakan didalam kelas, karena pada dasarnya keterampilan berpikir kritis mahasiswa dapat dilatih dan diasah dalam proses pembelajaran. L.M. Sartorelli dan R. Swartz dalam Hassubah (2004) menyatakan bahwa terdapat beberapa cara untuk meningkatkan kemampuan berpikir kritis diantaranya adalah: a) membaca dengan kritis; b) meningkatkan daya analisis suatu permasalahan dalam suatu diskusi dan mencari solusi terbaik serta menganalisis dampak terburuk dari permasalahan tersebut; c) mengembangkan kemampuan mengamati atau observasi selanjutnya menyebutkan kelebihan dan kekurangannya, pro-kontra dari pemasalahan yang diamati diharapkan akan menggali kemampuan kritis mahasiswa; d) meningkatkan rasa ingin tahu, kemampuan bertanya dan refleksi, pengajuan pertanyaan bermutu yaitu pertanyaan yang tidak secara langsung memiliki jawaban benar atau salah atau tidak hanya satu jawaban benar sehingga menuntut mahasiswa untuk giat berpikir. Keterampilan berpikir kritis dapat ditingkatkan dengan melaksanakan 

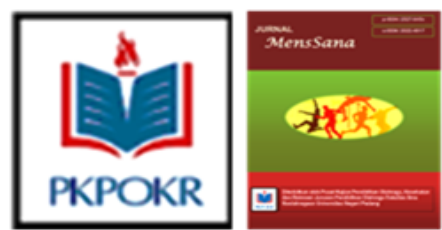

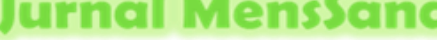

Vol. 4, No. 2; Tahun 2019

ISSN : 2527-645X, E-ISSN: 2622-4917

Penerbit:

Pusat Kajian Pendidikan Olahraga, Kesehatan dan Rekreasi.

Jurusan Pendidikan Olaharga, Fakultas Ilmu Keolahragaan, Universitas Negeri Padang

pembelajaran yang berpusat pada mahasiswa (student centered learning) (White et al., 2009).

\section{KESIMPULAN (5\%)}

Berdasarkan hasil penelitian dapat disimpulkan bahwa pengembangan buku ajar Ilmu Gizi Olahraga dapat meningkatkan kemampuan berpikir kritis mahasiswa Pendidikan Jasmani Kesehatan dan Rekreasi IKIP Budi Utomo Malang.

\section{DAFTAR PUSTAKA}

Adalikwu, S.A., dan I.T. Iorkpilgh. 2013. The Influence of Instructional Materials on Academic Performance of Senior Secondary School Students in Chemistry in Cross River State. Global Journal of Educational Research. 20 (1).

Departemen Pendidikan Nasional. 2008. Peraturan Nomor 2 Tahun 2008

TentangBuku.

http://mediainfo.sourceforge.net/.

Diaksestanggal 2 Januari 2013.

Direktorat Jenderal Pendidikan Tinggi. 2009. Pedoman Operasional Penilaian Angka Kredit Kenaikan Jabatan Fungsional Dosen ke Lektor Kepala dan Guru Besar. Jakarta: Kemendiknas.

Muslich, Masnur. 2010. Text Book Writing: Dasar-dasar Pemahaman, Penulisan, danPemakaian BukuTeks. Ar-Ruzz Media. Jogjakarta.

Thiagarajan, S., Semmel, D.S., and Semmel, M.I. $1974 . \quad$ Instructional Development for Training Teachers of Exceptional Children. National Center for Improvement of Educational. Washington.

Thiagarajan. 1974. Instructional Development for Training Teachersof Exceptional Children. University of Minnesota. New York-USA. 